\title{
Inter and Intra- Gender Discourse in African Prose: An Interrogation of the Female Image in Selected Literary Texts
}

\author{
Ebele Peace Okpala \& Tracie Chima Utoh-Ezeajugh \\ http://dx.doi./org/10.4314/ujah.v19i2.1
}

\begin{abstract}
Feminist writers have over the years portrayed patriarchy as the major and real source of female exploitation and subjugation and have highlighted the concept in their creative works. African female experiences, problems and yearnings are examined through the female character in the selected literary texts. Certain practices in the various cultural milieus, which not only demean women but also debar them from having a say in the daily affairs of the society are also exposed. The study interrogated some oppressive forces that marginalize women to determine if the factors are only inter gender. The paper revealed at the end of the study that truly women are subjected to discrimination, oppression and humiliation all through their lives and that these are both inter-gender and intra-gender. Patriarchy, as generally accepted, is not the sole source of female oppression because women seem to suffer oppression in the hands of fellow women especially in the African cultural milieu. The study employed the theories of Focu feminism, Snail Sense Feminism and Womanism in critical evaluations. To make adequate judgements, critical opinions of some scholars were reviewed. The study recommends love and empathy amongst women. It concludes that the oppression of women by the male gender will greatly be countered by women's collective activism, which can only be possible when they close ranks and unite.
\end{abstract}

Keywords: Gender, Patriarchy, Oppression, Intra Gender, Women. 


\section{Introduction}

Gender is the social attributes and capacities assigned to persons on the basis of their sexual characteristics Ogundipe-Leslie (152). Gender thinkers adopt a feminist stance and see no difference between genderism and feminism. The gender paradigm centrally addresses the problems of equality and liberty rights. The same can be said to feminism whose ideology basically consists of power, women, rights and equality. Feminism advocates change and generates political movements in form of women's movements in order to gain enough power and influence to effect the changes it advocates.

It motivates people to change their lifestyle, modify the existing social, religious, political and economic relations and encourage its followers to preserve what they value. Men are however portrayed as perpetrators of female-oppression and discrimination in a society which is viewed as male-dominated. According to Chinweizu, "feminist propaganda has sought to persuade the world that women are powerless in society, and that men are natural oppressors of women. It claims that wives are subordinate to their husbands in the home and that outside the home, men have excluded women from political, economic and cultural power" (9).

This paper discusses some oppressive forces that reduce women to second class status. It argues that men are not the major source of female exploitation and subjugation. The researcher examines the relationship that exists among the oppressed (women). The study highlights particularly how African women dominate, abuse, humiliate and oppress other women in some selected literary texts. It observes that gender warfare on women is as exploitative as male domination. Women should employ their 
God-given outrageous, audacious, courageous or willful behaviours as well as love for one another and team up to achieve a desired gender justice.

\section{Female Oppression in Selected Literary Texts}

The role of African women however seem to reinforce the walls of patriarchy the female writers aim to pull down. The researcher intends to study, the roles and reactions of women, (the oppressed) on their fellow women on issues concerning childlessness, marriage related issues and female circumcision, using some selected African literary texts. There seems to be a type of solidarity in adversity towards that which causes them so much pain.

\section{Childlessness}

The main purpose of marriage in Africa society is to bear children, to build a family and to extend life. Through marriage and child rearing, the parents are remembered by their children when they die. Childless marriage is a source of grievous disappointment and a major determinant of marital conflict, broken home, divorce and incentive for adding more marriages by the aggrieved husband (Anagbogu 7). It is very worrisome that despite people's exposure to Western civilization and education, attitude towards infertility still remains hostile. African society attaches much importance to children and inheritance. The philosophy of marriage emphasizes procreation more than even the relationship between the couple. A bride is expected to bear children within the first two years of marriage. Infertility in any African marriage is the woman's fault and the women themselves have been made to believe so even 
without any medical proof. A childless mother is regarded as a failure. "A woman is nobody, a wife is everything and a mother is next to God" (Spock, 39). "A Woman would be forgiven everything as long as she produced children" (Emecheta 28). Ideally, in a traditional African society, a barren woman is:

expected to marry another wife or wives for her husband. It is preferable that she does that because if she wastes time, two consequences may follow from that. He may either marry another woman with or without her consent or get a concubine who will bear children for him, he has to take one of these measures to restore his ego and prove his manhood. (Orabueze, 144)

Apart from this, many unsavoury names like he-woman, evil woman and witch are attached to a barren woman (Orabueze 107). Thousands of innocent women are tagged barren in Africa without proof. Efuru in Flora Nwapa's Efuru confides in Ajanupu without any medical examination, "I want my husband to have children, I am barren" (180). Amaka in Flora Nwapa's One is Enough, Awowa in Ama Ata Aidoos Anowa, Agnes in Nwapa's This is Lagos and Other Stories, Ije in Ifeoma Okoye's Behind the Clouds among others are victims of that circumstance. African traditional society has in many forms encouraged humiliation of childless mothers, "forcing them to consult various medicine-men, doctors, prophets or leaving their marital homes in frustration" (Nnolim 140).

Ifeoma Okoye calls for reexamination of the female image, suggesting that the man could also be the guilty party in a childless marriage. In her Behind the Clouds, she portrays the traditional attitudes to childlessness in African marriages and exposes the implication. Many other female writers have expressed in many 
ways the plight of barren women in Africa and the extent such women can go to have a child in other to save their marriage in a child-hungry society. The greatest problem is that the African female writers seem to be silent in the way and manner women maltreat their fellow women over this issue. Women, who ought to understand the condition of their fellow women better, seem to encourage and contribute to the destruction of women. Women seem to be their own enemies. Some are agents of destabilization, violence and humiliation on fellow women.

Childlessness constitutes the worst tyranny for married women and it defies any solution till date (Chukwuma 121). Agnes in Flora Nwapa's This is Lagos and Other Stories, driven to desperation, becomes a child thief. "In order to keep her marriage, she employs all kinds of deceit and finally resorts to stealing a baby from the hospital" (Nwapa 94). The agony of a barren woman is indescribable (Orabueze, 88). Emenyonu in his Tales of our Motherhood laments

Speak me to all barren women, she admonished as I strained my ears to hear her faint and dwindling voice. Speak me to all mothers who have only one child in a land and among a people where the value of a woman depends upon her capacity to fill her husband's house with children. Speak me to all who have a daughter as an only child ... speak me to all women who forfeited the love and respect of their husbands because they could not fill the dreams of multiple sons to inherit the men when they have joined the ancestors. (1)

The quotation depicts emphasis on discrimination, gender inequalities, injustice, degradation, humiliation and dehumanization that women experience in patriarchal society. In 
Ifeoma Okoye's Behind the Cloud, Beatrice, Ije's old school friend slept with a false prophet (Apostle Joseph) according to her,

My infidelity has saved my marriage for my husband was on the verge of sending me away and taking a new wife. If my marriage breaks down now at least I have a child who will look after me in old age. A childless woman in our society does not realize the extent of her handicap until she grows old. (61-62)

Due to extrangement from the society, infidelity which is debasing, which desecrates the santity of marriage, which cannot be condoned no matter the degree on which it is exercised; is boldly depicted as a virtue and a saviour of marriage. It is very important to examine "slandering, backstabbing, conniving, abusive women, woman on woman violence and abuse as subject of female analysis" (Obioma Nnaemeka, 90).

The attitude of mothers-in-law, sisters in-law, girl friends, concubines remain a source tension and stress and inflict so much pain on barren women. Dozie's mother and Virginia in Behind the Clouds are true examples. Dozie's mothers' case attracts moré concern and worry because Dozie is her only son. Virginia, the loose girl, captivated by Dozie's financial fortunes and prospects, sets a trap for him with her body, with intention of tricking him into a marriage that would guarantee her access to his wealth. After seducing him, she presents herself with a purported pregnancy and accuses him of being responsible (Nwabunnaya 265). The greedy Virginia aims to displace Ije Appiah from her matrimonial home. This attitude is even more exploitative than male domination. Amaka and Obiora in Nwapa's One is Enough are married for six years without a child. Obiora's mother reacts; 
I have waited for six years, and I cannot wait for even one day more. Didn't you see how I hushed up Obiora when he came to interfere? He is a stupid son. Sometimes I wonder whether he is my son... if my son heard me, if he had listened to me, his house would have been full of children by now. (13)

Nwapa's appears to state how brutal African husbands can be to their childless wives but she ignores the fact that; "there is no way a man can think out evil or carry it out against a woman without an active connivance of another woman. It does not lie his nature" (Orabueze, 167). African feminist overlook some of these negative roles played by some mothers-in-law. All Amaka needs is counselling and prayer and not harrassment or celebration of her misfortune. Her mother-in-law rather tells her to her face;

You are barren. That's all, barren. A year or so ago, you said you had a miscarriage. My son came to tell me. I laughed at him. I did not let him know that you were deceiving him. So my son's wife, you were never pregnant and you will never be. (14)

What could be worse than this? By a fellow woman, yet she claims to be fair, "I am not unkind to your wife. Other mothers would have thrown her out, not me. Amaka's mother, if she were in my shoes, would have thrown her out, not me... I am fair, and there is nobody fairer than I am in this community of ours" (15). If the fairest woman in that community could react to a childless daughter-in-law in this manner, what will the unkind ones not do? It is very obvious that woman encourage men to humiliate their wives. Omirima in Nwapa's Efuru is another backstabbing and evil schemer who destroys other woman in the novel. She instigates 
Gilbert's mother to find another wife for his son, citing Efuru's childlessness as the reason, "He cannot remain childless, his fathers were not childless. So it is not in the family. Your daughterin-law is good but childless" (163). Neighbours (including women) could not see any reason why her husband should not marry another woman since according to them two men do not live together. To them, Efuru was a man since she could not produce. Barrenness is a serious issue in African society and the barren woman expects sympathy not scorn and humiliation. Any woman who despises a barren colleague has given a voice to the male's maltreatment of childless woman (Awua 143).

The African woman carries a double yoke: to have plenty of children and to have male children in the majority. The birth of a male child unarguably heralds great jubilation. It can be a great disappointment for a woman's first fruit of the womb to be a girl (Orabueze 108). Ada, in Buchi Emecheta's Second Class Citizen:

was not even quite sure she was eight, because she was a girl. She was a girl who arrived when everyone was expecting and predicting a boy. So, since she was such a disappointment to her parents, to her immediate family, to her tribe, nobody thought of recording her birth. She was so insignificant. (7)

The woman also bears the blame since the African society, despite Western civilization "still holds on to a fallacy that has been debunked by science that a woman determines the sex of a baby" (Orabueze 109). Lewu equally highlights that:

due to the preference for boys in most cultures, a woman without a male child is almost regarded as barren. This is borne out of belief in male physical, psychological and social superiority. Only the male child is regarded as 
capable of perpetrating the lineage, while the female gets married into another family. Consequently, girls are treated as temporary members of their families, sometimes denied equal access to education, feeding and inheritance. (564)

In extreme cases in Igbo culture, where a man does not have an heir, one of his daughters may be kept in the house to continue the geneology of the man. She procreates after the traditional rites have been performed. This usually happens if the man loves the wife and does not want to inconvenience her with the presence of a second wife (Orabueze 89). In Akachi Adimora-Ezeigbo's The Last of the Strong Ones:

It was Aziagbo who solved the problem and save all of us from slow death. She was willing to remain at home with us to produce male children for her father. After we had performed the nluikwa ceremony, she chose Okonji as a mate. And he was willing to enter the relationship with her. It was a big relief to all of us. (33)

The rights of a woman in her husband's home depend on the number of male children she has. Unfortunately this outright humiliation is also aided by woman. Adaku in Flora Nwapa's Wives at War and Other Stories laments:

I have seen girls brought into my home by my mother-in-law for my husband. When I objected, she reminded me that she had four sons, and said that if I did not like what she was doing, I should go back to my parents with my band of girls. (45)

Due to the possibility of divorce, a woman is treated as stranger in her husband's family and the situation is worse if she is childless 
or has only female children. Women fight women even when "the battle and victory are for the benefit of men" (Utoh-Ezeajugh 138).

\section{Marriage Related Issues}

A girl's training from the onset is geared towards marriage. Emphasis is laid more on good behaviour, cleanliness, obedience and hardwork (Apena 282). This aims at creating harmony in the future home. "A girl's life, therefore was not accidentally but essentially a preparation for marriage. It was her great object in life. If she failed in that, she was considered to have nullified her existence" (J.P. Jordan 210). According to Nawal El Saadawi in her Women at Paint Zero, marriage was a system built on the most cruel suffering for women" (87). Wifehood is portrayed as the worst status of a woman. The women are subjected to physical violence and emotional turbulence.

Who inflicts pain, suffering and humiliation in marriage? Some women humiliate other women more in marriage. Marriama Ba recounts in So Long a Letter, with agony that there is nothing as humiliating as when a younger women displaces an older woman from her matrimonial home. Some women play dubious roles in marriage. Binetou's mother pressurizes her daughter to destroy the happiness of another woman. She encourages her to marry an already married man because of materialism. Materialism is often cited as the reason for marital displacement in many African societies. According to Awua;

... mother-in-law also contribute in making marriage a painful experience. Mothers regard the wives of their sons as displacing them in affection and do everything to cause disaffection in the homes of their children. Many sons over look the complaints by their wives of the humiliating 
manner their mothers treat them. This accords the mothersin-law absolute powers in the home. Therefore a mother-inlaw can drive a son's wife out of her matrimonial home. The mother-in-law can also pressurize her son into a second, third or fourth marriage. ... the wife is reduced to a nonentity and slave in her own home. (141)

It is unfortunate, that women themselves, hurt and make the lives of other women painful in marriage. The sisters-in-law are not left out. They consider their brothers' homes as theirs and the wives of their brothers as slaves or strangers. In So Long a Letter, Ramaloulaye's sisters-in-law leave their marital homes and live in their brother's home. These women subvert the legitimate roles of the wife and refuse to respect and obey their brother's wife in her own marital home.

Any woman who participates in the oppression and misfortune of another woman is evil. Women should co-operate with one another to fight marital disharmony and deprivation. Women should desist from being agents of destabilization and humiliation on fellow women. Modou, in So Long a Letter remains faithful to his wife until another woman lures him into another marriage. He then abandons his wife for a younger one. Polygamy would have phased out if women could respect the feeling and integrity of their fellow women and as such refuse to accept any marriage offer from an already married man. Mojola sums it:

... every woman who gets married to another married man and every woman who accepts the advances of a married man stands condemned as an oppressor of another, a usurper. (133). 


\section{Female Circumcision}

Circumcision of the clitoral prepuce is indeed an anatomical possibility, given adequate surgical instruments in a clinical setting. But such a delicate operation is nearly impossible to perform on struggling little girls and women on the cold floor of the bathroom or compound. Nor can it be properly carried out during initiation rites, within a framework of "sex education". (Tobe Levin, 207)

Nawal El Saadawi records, "my thighs had been pulled wide apart, and that each of my lower limbs was being held by steel fingers that never relinquished their pressure. Then suddenly the sharp metallic edge seemed to drop between my thighs and cut off a piece of flesh from my body. I screamed with pain despite the hand held over my mouth for the pain was not just a pain, it was like a searing flame that went through my whole body. After a few moment I saw a red pool of blood around my hips" (7-8). Evelyne Accad in her novel, L'Excisée equally expresses the horror of the tradition through the narrator, E., a foreigner who is forced to witness the 'slaughter' in her home. E narrates in the editor's translation how

the woman seized the first little girl held her on all sides. They raised her dress and made her sit on a stool that over lung a white basin. They spread her legs apart and exposed her shared pubic area. The mid-wife separated the Labia majora from the labia minora, whacked off the clitoris and tossed it into the basin. The girl wailed with pain, the blood running. The woman held the girl tighter. The sorceress continued her mutilation. She cut off labia majora, like large ears red with fright, that joined the clitoris in the 
basin... The little girl's cries sounded like those of a dog being slaughtered. $(121-122)$

Indeed, the clitoris severed from the body is a telling symbol of female status in phallocratic culture. Once amputation has occurred, no regeneration is possible (Tobe Levin 207). Tradition has made the women to believe that to become a woman, one must accept the knife. When $\mathrm{E}$ asks her husband how he can condone his compatriot's mutilation of women's "most delicate, most precious and most important sexual organs", reminding him that they had originally come together to his country as social revolutionaries, he replies "it's tradition" (Accad, 140).

The theme of female circumcision is expressed differently by different African writers. Nuruddin Farah in From a Crooked Rib demonstrates a high degree of feminist awareness in tackling the issue of infibulation. Yambo Ouologuem in Bound to Violence provides the means of reconstructing virginity after the ruler has "claimed for himself the right of the first night" (47). He ridicules male complacency and self-deception for demanding that 'purity' be feigned at such in human cost. The Egyptian physician and activist Nawal El Saadowi renders so sympathetically the initiate's state of mind during the 'massacre'. She recalls the rasping metallic sound which reminded her of the butcher when he used to sharpen his knife before slaughtering a sheep. According to her, "the memory of circumcision continued to track me down like a nightmare" (8).

Circumcision, according to Ebikere in Julie Okoh's Edewede is part of our culture. My mother was circumcised so also were her grandmother, great grandmothers and great, great grandmothers. It is a rite that every woman in this land goes through. (3) 
The playwright reassures that this obnoxious cultural practice is as a result of ignorance and superstitution. She equally portrays that the practice is "detrimental to the women folk and froth with all kinds of infections for the women" (Ebo 244). In the words of Edewede; "Circumcision has destroyed many women in this village. They suffer from different types of infections and complications after the operation". (30)

Quoting, Eriala (Mama Nurse) she (Edewede) points out;

During circumcision, when the clitoris is being removed; the labia and the surrounding tissues are damaged. The girl suffers from stenosis that is healing with the narrowing of the birth canal. Later in life, during labour the narrowed birth canal makes it difficult for the baby to come out easily. The baby's head is forced to create an opening between the walls of the bladder, urethra and the vagina. If a woman survives, she begins to leak urine because the damaged bladder, urethra or vagina outlet can no longer control the urine. (31)

Although, most female circumcision is culture-oriented, Okoh reassures that women can in a non-confrontational manner fight this war and win it. They should only come together and express their grievance using any weapon that can make men listen to their plight and request.

Saadawi deals with the theme of female circumcision from a non-compromised perspective. According to her mutilation is a permanent and extremely serious violation of integrity that cannot be condoned. In The River Between, Ngugi wa Thiongo deals with female circumcision from a humanist point of view and not feminist. The issue serves as a battlefield in the clash between conservative tribal elements and the patriarchal Christian church in 
Kenya. Female circumcision is equated with the return to traditional kikuyu values, hence resistence to its abolition confirms an oppositional gesture against colonialism (Levin 210). According to Stella Efua Graham of Ghana, female circumcision is a very sensitive and political subject tied to complex socio-cultural structure and to underdevelopment. It is directly related to the depressed political and socioeconomic position of women in these societies (3).

What is the attitude of women, the depressed, oppressed and massacred in these societies? Their attitudes seems to confirm full support and endorsement of the act. The circumcision is performed by woman in the presence of other women. According to El Saadawi, I "did not know what they had cut off from my body... I just wept, and called out to my mother for help. But the worst shock of all was when I looked around and found her standing by my side" (8). In Accads L'Excisée, female solidarity in suffering is portrayed in the perpetuation of that humiliation, for the women present at the massacre scream and clap to drown out the cries of the children taking this revenge (121).

According to El Saadawi, female circumcision is part of the patriarchal package that involves cutting the sexual organs of female children, especially the clitoris to guarantee their virginity before marriage and their fidelity after marriage. As a medical doctor and a psychiatrist, she emphasizes that female circumcision has nothing to do with the morality of women, it does not make them more monogamous or more faithful to their husbands. On the contrary, cutting the clitoris increases women's sexual desires, for two reasons, because the brain is the main site of sexual desires and because circumcised women have difficulty reaching sexual satisfaction with their husbands, they look for this satisfaction outside marriage (194). To eradicate this deep-rooted custom, she 
believes, 'there must be combined efforts to mobilize men, women, youths and children so that they become organized and constitute a political and social power capable of changing the existing patriarchal values and laws" (195). She sums that women should stand firm and reject the medicalization of female genital mutilation for it is a crime and should not be done either by safe or unsafe methods, in a mild form or in a semi-mild form.

\section{Conclusion}

Women have the capacity to become architects of their own destinies and decide whether to be included or excluded in the scheme of things (Utoh-Ezeajugh 150). There is much in femininity that can change the world. Such qualities that adorn female personality include patience, empathy, love, sensitivity and endurance (Awua 145). A woman has all it takes to run her world "by running the man who runs the world for her" (Chinweizu 75). Women exercise the most effective sanction against misrule in some African traditional societies. "when a king becomes intolerable to his subjects, a procession of grandmothers will march naked to his palace.

No ruler survives this final and dramatic reputation by the mothers of his subjects" (Chinweizu 70). Salami equally confirms that women have been voted globally to use collective action to mount pressure on the authorities in order to liberate themselves from one form of oppression or another (423). Women should cherish their nature and femininity. Women should love and appreciate their fellow women. Their culture, predicament, plight, experience and power should be seen by fellow women as something that have universal significance. It is only when women 
stop persecuting one another that they can redress the very many prejudices that have reduced them to second-class status.

\section{Ebele Peace Okpala}

Department of English Language and Literature

Nnamdi Azikiwe University, Awka. nneakunauba@gmail.com $\&$

\section{Tracie Chima Utoh-Ezeajugh}

Professor of Theatre and Film

Design

Department of Theatre and Film Studies

Nnamdi Azikiwe University Awka

Nigeria.

traciechima@yahoo.co.uk

t.utoh-ezeajugh@unizk.edu.ng

\section{Works Cited}

Accad Evelyn. L'Excccisée Paris: L'Harmatan, 1982. Print. Acholonu, Catherine, Motherism: The Afrocentric Alternative to Feminism. Owerri: Afa Publication, 1995. Print.

Acholonu, Rose. "Beyond Feminism: The Harvest of Accommodationist Love". Journal of Modern Languages Association of Nigeria (JMLAN), Vol. 2, 1994, p. 42. Print. 
Family Love in Nigerian Fiction: Feminist Perspectives. Owerri: Achisons Publishers, 1995. Print.

"The Female Predicament in the African Novel". In Chukwuma, Helen (ed). Feminism in African Literature. Enugu: New Generation Books, 1994, 38 - 52. Print.

Adimora-Ezeigbo, Akachi. The Last of The Strong Ones. Lagos: Vista Books, 1996. Print.

. . Snail Sense Feminism: Building on an Indigenous Model (Monograph series). Lagos: Wealthmith Books, 2015.

Aidoo, Ama Ata. Anowa. London: Longman group Ltd, 1970. Print.

Anagbogu, M.A. "A handbook on Problems of the Youth: A Psychological Approach to Behavioural Change". Benin: Olivet Publishing Company. 1995. Print.

Apena, Adeline. "Bearing the Burden of Change: Colonial and Post Colonial Experience in Flora Nwapa's Women Are Different". In Umeh, Marie (ed). Emerging Perspectives on Flora Nwapa: Critical and Theoretical Essays. Asmara: African World Press, 1998. 277 - 289. Print.

Asigbo, Alex, \& Emeka Nwosu. "Feminist Aesthetics and the Womanist Agenda: A Re-Reading of Zulu Sofola's The Sweet Trap." In The Artist: A Journal of Theatre Studies and the Humanities, I.I. Ed Emeka Nwosu Owerri: Department of Theatre Arts Imo State University, Sept. 2008. Print.

Awua, Benjamin Ityoakaa. "Women on Women Violence: A Survey of Women Characters in Mariama Ba's So Long A Letter and Flora Nwapa's Efuru". Fender Studies: A Reader. Okoli, F.C. et al (eds). Nsukka: Great AP Express Publishers, 2010. 139 - 145. Print.

Ba, M. So Long a Letter. Ibadan: New Horn Press Ltd, 1980. Print. 
Banyinwa-Horne, Naana. "Flora Nwapa's This is Lagos:

Valorizing the Female through Narrative Agency". In Umeh, Marie (ed). Emerging Perspectives on Flora Nwapa: Critical and Theoretical Essays. Asmara: African World Press, 1998. 441 - 476. Print.

. . A African Womanhood: The Contrasting Perspectives of Flora Nwapa's Efuru and Elechi Amadi's The Concubine". In Davies, Carole Boyce and Anne Adams Graves (eds). Ngambika: Studies of Women in African Literature. Trenton, New Jersey: Africa World Press, 1986. 1119 129. Print.

Chinweizu Anatomy of Female Power: A Masculinist Dissertation of Matriachy. Lagos: Lagos Pero, 1990. Print.

Chukwuma, Helen. "Flora Nwapa is Different". In Chukwuma, Helen (ed). Feminism in African Literature. Enugu: New Generation Books, 1994. 115 - 130. Print.

Chukwu, Ugochukwu. "Politicized Ontology: The Kpim Factor in Women's Oppression Reconstructing and Rebuilding Human Communities beyond Gender Lines". In The Kpim of Feminism: Issues and Women in a Changing World. Eds. Ukagbo, George Uzoma, Obioma Des-Obi, Iks J. Nwankwo. Victoria, Canada: Trafford Publishing, 2010. 556 - 566. Print.

Ekwensi, C. Jugua Nana. London: Heinamann, 1982. Print. Emecheta, B. Second Class Citizen. London: Fontana, 1974. Print. Emenyionu, Ernest. Tales of our Motherland. Ibadan: Heinemann, 1980. Print.

Graham, Efua Stella. "Female Sexual Mutilation", In Minority Rights Group Newletter, No. 15, April 1983. London: 36 Craven Street, W C3 p. 3. Print. 
Iwuchukwu,

Onyeka.

Focu

Feminism

http://www.academia.edu/34734890/OFO_JOURNAL_OF _TRANSATLANTIC_STUDIES.

Jordan, J.P. Bishop Shanahan of Nigeria. Dublin: Eco Press, 1971.

Print.

Levin, Tobe "Women as Scapegoats of Culture and Cult: An Activists View of Female Circumcision in Ngugi's The River Between". In Ngambika Studies of Women in African Literature. Eds carole Boyce Daries \& Anne Adams Graves. Trenton: Africa World Press, 1986. 205 - 221. Print.

Lewu, M.A.Y. "Discrimination against Women in Nigeria: An Overview". In Gender Discourse in African Theatre, Literature and Visual Arts. A Festchrist in Honour of Professor Mabel Evwierhoma. Eds. Tracie Utoh-Ezeajugh Barcclays Foubiri Ayakoroma. Ibadan: Kraft Books Limited, 2015. 563-573. Print.

Lucas, Joseph, M. "The Drama of Women Exploitation and Victimization in Irene Salami-Agunloye's Sweet Revenge" In Feminist Aesthetics and Dramaturgy of Irene SalamiAgunloye. Ed. Emmy Idegu. Jos. Department of Theatre Arts, UNIJOS 2009: 114-133. Print.

Mojola, Ibiyemi. "The Onus of Womanhood: Mariama Ba and Zaynab Alkali". In Writing African Women: Gender, Power, Culture and Literature in West Africa. Ed. Stephanie Newell. London: Zed Books, 1977. Print.

Ngugi wa Thiongo. The River Between. London: Heinemann. 1965. Print.

Nnaemeka, Obioma, Sisterhood, Feminism and Power. Trenton: African World Press, 1998. Print. 
Nnamani, Amuluche-Greg. "Women Struggle in the Pre-Colonial and Colonial Nigeria: Lessons for Modern Feminism". In The Kpim of Feminism: Issues and Women in a Changing World. Eds. Ukagbo, George Uzoma, Obioma Des-Obi, Iks J. Nwankwo. Victoria, Canada: Trafford Publishing, 2010. 212 - 223. Print.

Nnolim, C. Approaches to African Novel: Essay in Analysis. Port Harcourt: International Publisher, 1990. Print.

, Morning yet on Criticism Day: The Criticism of African Literature in the twentieth Century. Port Harcourt: University of Port Harcourt Press, 2009. Print.

Issues in African Literature. Yenagoa: Treasure Resource Communications Limited, 2009. Print.

Nwahunanya, Chinyere. Literary Criticism, Critical Theory and

Post Colonial African Literature. Owerri: Springfield Publsihers Ltd, 2010. Print.

Nwapa, Flora One if Enough. Enugu: Tana Press, 1981. Print. Women Are Different. Enugu: Tana Press, 1986. Print.

'Women and Creative Writing in Africa'. In Nnaemeka

- . Obioma (ed). Sisterhood, Feminism and Power: From Africa to the Diaspora. Asmara: African World Press, 1998. 89 - 99. Print.

Efuru. London: Heinemann, 1966. Print

Nwosu, Chukwuma C. "Sex Role Stereotype and Women Empowerment in Tess Onwueme's The Reign of Wazobia”. In Nigeria Academic Forum: A Multidisciplinary Journal, 6. 5. Ed. Nonso Nnabuife. Awka: National Association of the Academic, 2004. Print.

"Theatre and Better protection for Women and Children in Nigeria: A Study of Tess Onwueme's Theatre". In Theatre 
Experience: A Journal of Contemporary Theatre Practice, 2 . 1. Ed. Emma Ejiofor Ebo, Awka: Department of Theatre Arts, Nnamdi Azikiwe University, 2003. Print.

Ode, Regina. "Strategies for Articulating the Women Empowerment Question in Nigeria" in Gender, Power and Politics in Nigeria. Makurdi: Aboki Publishers. 2007. Prints.

Ogundipe-Leslie, Molara. "The Female Writer and Her Commitment". In Women in African Literature Today. A review. Eds Eldred Durosims Jones, Eustace Palmer Marjorie Jones. Trenton: African World Press, 1987. 5-13. Print.

"Sturanism: Feminism in African Context". In African . . Literature: An Anthology of Criticism and Theory, 2010, 540 - 550. Print.

Ogunyemi, Chikwenye. "Woman and Nigerian Literature".

Perspectives on Nigerian Literature. Vol. 1 Lagos:

Guardian Books, 1988. Print.

Oko, Julie. Edewede (The Dawn of a New Day). Owerri: Totan Publishers Ltd. 2000. Print.

Okoye, Ifeoma, Behind the Cloud. London: Longman, 1982. Print. The Trial and Other Stories. Lagos: African Heritage Press, 2005. Print

Onwueme, Tess. The Broken Calabash. Owerri Totan, 1984. Print. Orabueze, Florence O. "The Feminist Crusade Against Violations of Women's Fundamental Human Rights: Mariama Ba's So Long A Letter and Buchi Emecheta's Second Class Citizen". In Women in the Academy Festschrift for Professor Helen Chukwuma. Eds Seiyifa Karoye, Noel C. Anyadike. Port Harcourt: Pearl Publishers, 2004. Print. 
Society, Women \& Literature in Africa. Port Harcourt: M \& . . . J Orbit Communications Ltd, 2010. Print.

"The Prison of Nigerian Woman: Female Complicity in

. . . Sefi Atta's Everything Good will Come" in New Novels in African Literature Today 27. Eds Emenyonu, Nana Wilson - Tagoe, Patricia T. Emenyonu. Ibadan: GLT Press, 2010. 85 - 102. Print.

Ouologuem, Yambo. Bound to Violence. Trans Ralph Mannheim. London: Heinemann, 1971. Print.

Saadawi El Nawal. "The Struggle to End the Practice of Female Genital Mutilation" in African Women Writing Resistance Anthology of Contemporary Voices. Eds. Jennifer Browdy de Hernandez, Pauline Dongala, Omotayo Jolaosho, Anne Berafin. Cape Town: Pambazuka Press, 2011. 192-197. Print.

. . . The Hidden Face of Eve. Women in the Arab World. Trans. Sheriff Hetata. London: Zed Press, 1980. Print.

Woman at Point Zero. London: Zed Books, 1983. Print.

. . . Irene Isoken. "Female Consciousness and Collective Action in The Wives Revolt and More than Dancing". In Nigerian Theatre Journal, 8 . 1. Lagos: Society of Nigerian Theatre Artists (SONTA), 2005: 422 - 432. Print.

Spock, B. Baby and Children. London: Routledge, 1992. Print. Udenta, O Udenta. Revolutionary Aasthetics and the African Literary Process. Enugu: Fourth Dimension Publishing Company Ltd, 1993. Print.

Utoh-Ezeajugh, Tracie. "Nigerian Female Playwrights and the Evolution of a Literary Style: Gendered Discourse in the Plays of Tess Onwueme, Irene Salami-Agunloye and Tracie Utoh-Ezeajugh", in Gender Discourse in African Theatre, Literature and Visual Arts. A Festschrift in 
Honour of Professor Mabel Evwierhoma. Eds. Tracie Chima Utoh-Ezeajugh, Barclays Foubiri Ayakoroma. Ibadan: Kraft Books Limited, 2015. 133-154. Print.

Walker, Alice. In Search of Our Mothers' Garden. New York: Harcourt Brace Jovanovich, 1984. Print. 